\title{
An Empirical Study on the Factors Affecting the Interest Rate Spread of Listed Conventional Commercial Banks of Bangladesh
}

\author{
Washeka Anjom
}

\section{ABSTRACT}

\begin{abstract}
This paper aims to explore the factors affecting the interest rate spread of the listed conventional commercial banks of Bangladesh from 2011 to 2019. For this, banks' interest rate spread has been considered a dependent variable while bank-specific, industry-specific, and macroeconomic factors have been considered independent variables. Bank-specific factors are credit risk, bank size, operating cost, liquidity risk, net interest income, capital adequacy, return on equity. The bank industry-specific factor is market share, while macroeconomic factors are GDP and Inflation. Pooled Ordinary Linear Regression analysis and the random-effect method have been used to investigate the impact of the factors on interest rate spread. The results demonstrate that credit risk, operating costs, and liquidity risk positively impact interest rate spread. The asset size and GDP have both positive and negative relationships depending on the circumstances. In contrast, net interest income, capital adequacy, return on assets, and market share have a negative relationship. The study's findings will assist the regulatory body of the banks in developing strategies to maintain a satisfactory level of interest rate spread.
\end{abstract}

Keywords: Credit risk, Interest rate spread, Loan market power, Risk aversion.

\author{
Submitted : September 01, 2021 \\ Published : October 17, 2021 \\ ISSN: $2507-1076$ \\ DOI: $10.24018 / \mathrm{ejbmr} .2021 .6 .5 .1086$ \\ Washeka Anjom* \\ Senior Lecturer, Department of Business \\ Administration, Port City International \\ University, Bangladesh. \\ (e-mail: adnin09@yahoo.com)
}

\section{INTRODUCTION}

Bank, a vital component of a country's financial system, contributes to the remarkable progress of the economy by playing its intermediation role. Bank paves the way for economic development through financial intermediation, facilitating capital formation, and fund mobilization. Unlike in other developed nations, where financial markets and the banking system work in unison to channel those funds, financial markets are undersized and sometimes wholly absent in developing countries. It falls on the banks to bridge the gap between savers and borrowers and to perform all tasks associated with the profitable and secure channeling of funds [1]. The dominance of banks in South Asian countries can be explained by various factors, such as the underdevelopment of the capital market. The level of efficiency of banks in financial intermediation is reflected by the interest rate that banks charge on loans and the interest rate they disburse on deposits [2]. One of the economic factors that influence economic growth. In other words, bank efficiency can be achieved through proper utilization of its asset that links to interest rate spreads.

Banks are profit-seeking organizations. They have to earn sufficient income to meet up expenses associated with providing financial services to diverse clients. This income consists of interest income and non-interest income. At the same time, fees include the cost of funds, operating expenses, and costs incurred to fulfill the requirement of the regulatory body of banks, i.e., the central bank. So, banks ensure that the interest rate on lending is greater than the interest rate on deposits. The interest rate on deposits represents a cost to the banks, while the interest rate on lending generates income for the banks. Therefore, the difference between the interest rate on deposits and interest rate on lending is known as interest rate spread (IRS). Literature also exhibits several meanings of interest rate spread. The difference between the credit interest rate and the debt interest rate is called interest rate spread [3]. The spread rate is the difference between the debts and assets rates [4]. Difference between interest income received and interest paid by a bank as a ratio of total assets or difference between the ratio of interest received and all interest-bearing assets and the ratio of interest paid and all interest-earning liabilities [5].

The Interest rate spread (IRS) can be simplistically defined as the difference between the interest rate charged on the borrowers and the rate paid to the depositors [6]. Interest rate spread also represents the compensation to the bank for bearing the risk of loan defaults and risk to the cost of funding. There have been many works in developed and developing countries concerning the spread of commercial banks, such as Kenya, Africa, Oman, Iran, Pakistan, Indonesia, and Bangladesh. Developing countries demonstrate higher IRS than those in developed countries. There is a high interest rate spread in Kenya due to banks' crucial role in the country's economic acceleration. The high interest rate spread of the African economy reduces the saving of individuals due to the low deposit rates offered by the banks. And also, it contracts the demand for loans due to the higher lending rate. 
Consequently, it would affect the economy adversely in a bank-based economy like Africa [7]. In Oman, Increased competition in the banking sector results in widely financial inclusion, which impacts the banking sector's upward interest rate spread and profitability. Reforms in regulations in Indonesia have an eventual effect on the interest rate spread of banks [8]. However, in Bangladesh, a higher interest rate spread limits the funds to potential borrowers, leading to reduced investment growth in the economy. A higher interest rate spread in developing countries is a barrier for fund mobilization as it disheartens potential savers and investors to save and borrow. It causes a reduction in lending, investment, and eventually, the economic growth of an economy. However, a lower level of margin can ensure a better supply of money, facilitating economic growth and enhancing the efficiency of banks [9]. So, in line with empirical research, interest rate spread may be high or low depending on the factors that affect it. Thus, this present study intends to investigate the factors affecting the interest rate spread of listed conventional commercial banks of Bangladesh.

\section{INTEREST RATE SPREAD OF LISTED CONVENTIONAL BANKS OVER TIME}

It is a well-known fact that the banking industry of Bangladesh had started its journey after independence, i.e., 1971. Since then, Bangladesh has high IRS relative to both global and domestic standards. Financial reforms in Bangladesh in the $1980 \mathrm{~s}$ led to cause interest rate deregulation in 1989, which had given the flexibility to respective banks in the determination of lending and deposit rate. Since then, Bangladesh Bank had set the upper and lower limit of interest rates to every bank so that individual banks can determine their own interest rates within the limit. By virtue of this, banks were able to set lending and deposit rates in 1990 under the financial sector reform program, reflecting the happening of financial sector liberalization in Bangladesh (Source: Bangladesh Bank). After that, upper and lower limits of rates and other restrictions were removed in 1999, making banks set their rates based on market conditions. Since then, banks have got an opportunity to enjoy greater flexibility in setting interest rates. After that, Bangladesh's interest rate spread was intended to decrease throughout 2000-2019, ending at 2.78\% in 2019 (Source: World Bank). In March 2020, the interest rate spread rose to $4.07 \%$, which further declined to $2.92 \%$ in April 2020 due to the execution of the single-digit interest rate in the banking sector (Source: Bangladesh Bank). In December 2020 interest rate spread of banks rose to $3.07 \%$. A larger inflow of funds in the banking system causes to cut the deposit rates leading to the increase of interest spread in December 2020.

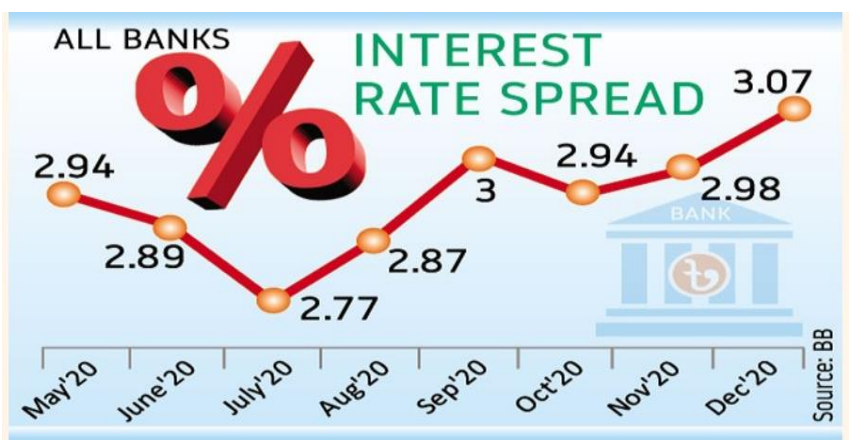

Fig. 1. Monthly interest rate spread (\%) of all banks during 2020.

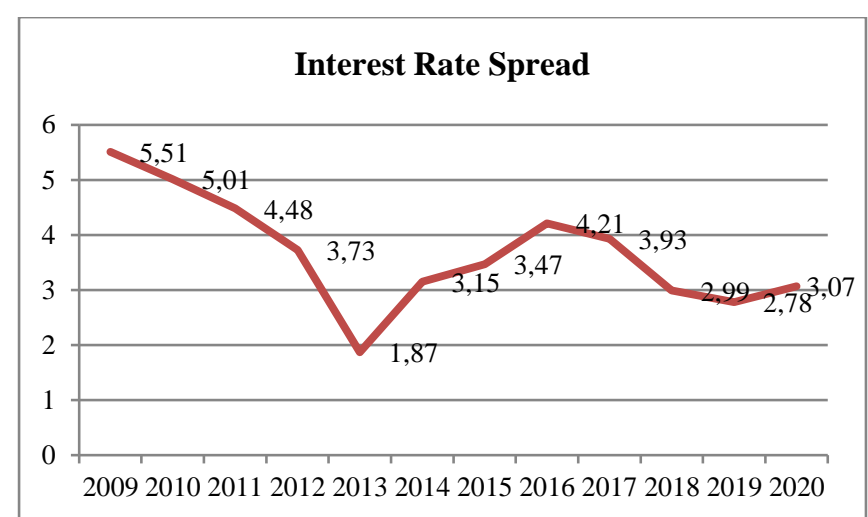

Fig. 2. Yearly interest rate spread (\%) of all banks from 2009 to 2020.

\section{SignifiCANCE OF THE STUDY}

IRS, one of the measures of the bank efficiency and crucial factor of banks' profitability, has become a significant issue regarding the factors that affect the level of IRS of commercial banks. The interest and non-interest (Commissions, fees, etc.) income and the cost of doing banking business determine banks' profitability. Banks need to price the loan appropriately to cover the cost of the fund while maintaining a satisfactory level of profits. While the primary source of income of banks relates to the loan proceeds, the cost of a fund associated with fund collection represents the prime expense. So, maintaining a steady level of interest rate spread is significant to balance between the cost of fund and receipt of interest income. Therefore, it is crucial to realize the behavior of the commercial banks in the formation of interest rate margin to enhance economic growth and assess the efficiency of the banking industry. So, the present research work on the factors affecting the interest rate spread of listed conventional commercial banks of Bangladesh will guide the bank regulators and employees to formulate a strategy that would ensure the stabilization of the banking sector of an economy.

\section{A. Contribution to the Existing Literature}

The present study extends the empirical research works done by several researchers both in developed and developing countries. This study has contributed to the existing literature with new research findings that add value to knowledge insight. Bank regulators will develop sophisticated strategies in the challenging situation with the findings of this work. The research time frame of this work includes when the banking sector has faced the threats arising from the Covid19 pandemic. In this Covid-19 pandemic, the research work on the factors affecting the interest rate spread of listed 
conventional commercial banks of Bangladesh is hardly found to the best of my knowledge in the existing literature.

\section{B. Problem Statement}

This high interest rate spread is caused by many factors evidenced in the existing literature. Many researchers opine that a high-interest rate is caused by internal factors of banks and macroeconomic and bank industry factors. The impact of the elements on the interest rate spread will vary from one country to another. Factors such as Liquidity Risk, Return to Asset Ratio, Capital Adequacy, Cost Efficiency Ratio, and Risk Aversion can significantly affect interest rate spreads as well as all economic variables such as GDP and inflation affect significantly on the interest rate spread of conventional banks in Indonesia. Jamil \& Shubiri [3] state that return to asset ratio, liquidity risk and risk aversion unemployment rate, debt services ratio and principal repayment, and market indicators like the Herfindahl-Hirschman index affect the interest rate spread of commercial banks of Oman. Capital adequacy, credit risk, operating costs, degree of competition, and deposit growth rate are the most critical factors affecting the net interest margins of commercial banks of Ethiopia, as found in a study by Leykun [10]. In Bangladesh, they are operating costs, classified loans, inflation, market share of deposits, statutory reserve requirements, taxes, and noninterest income impact the interest rate spread of conventional commercial banks. Researchers of the developing countries worked on IRS determinants, which differ from one to another depending on the chosen research time frame, variables, and methodology. However, in Bangladesh, very little work is done on the factors affecting the interest rate spread of conventional commercial banks of Bangladesh, showing the combined impact of bank-specific factors, bank-industry factors, and macroeconomic factors on the interest rate spread. And also, present study includes a research time frame in which the banks had faced several issues like the global meltdown in 2008 , compliance to the regulations like risk-based capital adequacy framework, increased competition from new entrants, and macroeconomic shock as Covid-19. This way, the present study distinguishes it from existing literature. It would generate new empirical evidence with work done in pandemic situations and the inclusion of the factors from multiple dimensions. So, the paper aims to investigate the factors affecting the interest rate spread of the conventional commercial banks of Bangladesh.

\section{Research Objective}

The prime research objective of the study is to investigate the factors affecting the interest rate spread of listed conventional banks of Bangladesh, highlighting the bankspecific factors, bank-industry-specific factors, and macroeconomic factors altogether.

\section{Research Hypothesis}

The present study intends to formulate these following research hypotheses:

H1: Bank specific factors affect the interest rate spread of banks

$\mathrm{H} 2$ : Bank-industry specific factor affect the interest rate spread of banks.
H3: Macroeconomic factors affect the interest rate spread of banks.

\section{LITERATURE REVIEW}

Over time, there have been several studies on the interest rate spread of commercial banks in many countries. The empirical works on interest rate spread identify many factors affecting the interest rate spread and its impact on profitability in the context of both developed and developing countries. However, in Bangladesh, there exist very few studies on the interest rate spread of commercial banks. So, keeping inconsistency with the previous studies, this section is covered by the theoretical framework and empirical findings on the interest rate spread of commercial banks.

\section{A. Theoretical Foundations}

In determining the interest margin of banks, the most significant theoretical framework is called the bank dealership model developed by Ho and Saunders in 1981. In this model, the bank, a risk-averse dealer in the credit market, plays financial intermediation between the suppliers and demanders of funds. This model seeks to explain the bank interest margins on the uncertainties related to deposit and loan markets. According to this model, Banks obtain deposits in random intervals while banks utilize those funds on the stochastically received loan requests. This randomness, followed by the uncertainty in the deposit receipt and the stochastic manner in which clients request loans, creates an inventory risk for banks. This risk requires to be compensated through a spread between loan and deposit rates called pure interest spread. However, Ho and Saunders identified four variables to impact the size of the interest rate spread. These are the degree of managerial risk aversion, average transaction size, competition within the bank market, and the interest rates' variability. However, Ho and Saunders's model is modified by several researchers over time.

McShane and Sharpe [11] opine that banks, being the player of intermediation between depositors and borrowers, seek to maximize the risk aversion and expected utility in the credit market (loan and deposit markets). Interest rate is viewed as fees for performing financial intermediation based on the randomness of the deposit receipt and loan requests and uncertainty in short-term interest rates. However, they concluded a linear relationship between banks and market power, the degree of risk aversion, interest rate uncertainty, and average transaction cost.

In a study by Allen [12], banks were viewed as passive dealers. That's why they change their prices depending on the demand for loans as well as deposits. He states that the loan rate is determined by the discounted default risk-adjusted true price of the loan, and the deposit rate is set by imposing a mark upon the default risk-adjusted true price of the deposit. However, monopoly power and risk premium are influential factors of interest rate spread.

\section{B. Empirical Findings}

Indriati et al. [8] explored the influential factors affecting the interest rate spread of conventional banks listed on the Indonesia Stock Exchange from 2013 to 2017. Using the OLS regression model, they have exhibited bank factors such as 
Liquidity Risk, Return to Asset Ratio, Capital Adequacy, Cost Efficiency Ratio, Risk Aversion, etc. affect the interest spread.

All economic variables used also have an impact on the interest spread. And also, among five macroeconomic factors, GDP and inflation significantly affect the interest rate spread of conventional banks. Very few studies have been found in empirical research showing the impact of the financial bank, macroeconomics, economic freedom, and market structure variables on the interest rate spread.

Gakpetor et al. [13] undertake a study on the impact of interest rate spread on the bank profitability in Ghana on 24 banks over 2003-2016. The study results show a positive and statistically significant association between interest rate spread and bank profitability in Ghana. The bank will increase the net interest margin by effectively and efficiently growing interest income and decreasing interest expense to improve profitability. The results suggest that policies aimed at reducing interest rate spread in Ghana should make credit facilities available at a cheaper rate to compel commercial banks to reduce the interest rate. Ahamed [14] identified that liquidity risk significantly increases the increase rate and increases the spread.

Jamil \& Shubiri [3] assess the determinants of interest rate spread of listed commercial banks of Oman from 2008 through 2014 by employing OLS regression and the Spearman Correlation Matrix. They categorize the determinants into four dimensions such as financial, economic, market, and legal indicators. Results show that financial indicators such as return to asset ratio, liquidity risk, and risk aversion significantly impact interest rate spread. Economic indicators such as unemployment rate, debt services ratio, and principal repayment and market indicator like Herfindahl-Hirschman Index based on market concentration group have a statistically significant impact on the interest rate spread of commercial banks of Oman. And also, Legal variables such as sound money and regulation contribute to the interest rate spread. However, it did not use a panel data approach for better and realistic results.

Rostami \& Ghasemi [4] investigated the influential factors of interest rate spread of an Iranian bank during the last 19 months and developed a suitable spread rate model for Iran's banking industry. The variables considered for the study are NPL ratio, ratio of demand deposits on deposits, non-interest income, and income-earning assets to total assets, capital adequacy ratio, ROA ratio, and inflation and exchange rate. Findings of the study reveal that NPL, demand deposits on deposits, capital adequacy, and ROA positively correlate with interest rate spread. In contrast, non-interest income, exchange rate, inflation have a negative correlation with interest rate spread.

Nyalihama et al. [15] explore the determinants of interest rate spread of banks in Rwanda by using Arellano-Bond dynamic panel data Generalized Method of Moments (GMM) estimation. The results demonstrate that credit risks, operating costs, and inflation positively influence the interest rate spread in Rwanda. They recommend that banks formulate mechanisms to sort out potential defaulters and strengthen their credit management strategies to reduce credit risk. Hossain \& Ahamed, [16] identified that non-interest income has direct correlation with the profitability therefore reducing the interest rate spread. The return on assets, capital adequacy and deposits are significantly correlated with determination of interest rates. The same conclusion generated by Hossain \& Ahamed [17] including the macroeconomic variables. Ahmed [18] found that management capacity and board influence substantially affect the loan interest rate.

Fofack [7] conducts a study on the determinants of interest rate spread of banks in the Central African Economic and Monetary Community (CAEMC) member countries from 2000-2010 by concerning bank-specific characteristics, industry factors, macroeconomic variables. Bank assets, doubtful loans, and the volume of credit are found to impact the spread significantly. From a macroeconomic perspective, oil rents, foreign direct investment (FDI) inflows, and real gross domestic product (GDP) growth significantly affect banking spread. He also considers some institutional factors affecting the bank spread, such as political stability, corruption, government effectiveness, regulatory quality, and bank concentration in the deposit market. Macro elements are influential in explaining interest spread than micro factors. Khan [19] used ordinary least square method to identify the impact of inflation on GDP growth. He found that GDP has direct correlation with macroeconomic variables such as inflation, interest rate and exchange rate [20].

Leykun [10] found that capital adequacy, credit risk, operating costs, degree of competition, and deposit growth rate are the most critical factors affecting the net interest margins of commercial banks of Ethiopia from 2005 to 2014. However, no macroeconomic factor has been considered here as well as a small number of variables has been chosen here. It is recommended that banks decrease the banks' concentration ratio, operating costs, the risk premium on credits, and enhance the level of capital to offer competitive interest margins and fairly shared growth rates in deposits, among others. Mohammad \& Mohammad [21] the dynamics of savings and investment option reduces the interest rate gap and enhance capital mobility. Alam, et al. [22] reached the similar conclusion while studying the financial system in Bangladesh.

Kagiri et al. [23] explore the Determinants of Interest Rate Spread of Commercial Banks in Kenya from 1036 credit officers of banks by using questionnaires. They sought responses from the credit officers of four commercial banks to study variables considered for the study. The inflation rate, credit risk, liquidity ratio, and returns on average assets impact the interest rate spread of commercial banks of Kenya. However, the variables chosen for the study are too few to get a robust result.

Wambua \& Were [6] conduct a study on the drivers of interest rate spread of banks in Kenya throughout 2002-2011 using panel data. The results demonstrate that bank-specific factors such as bank size, credit risk, return on average assets, and operating costs positively influence interest rate spreads of banks. In contrast, bank liquidity has a negative effect on the spread. And also, real GDP, inflation, and monetary policy are insignificant in affecting the spread. However, they did not incorporate any impact of the bank-industry variable on the spread of banks. Minar [24] [25]. figured out that the mobility of immigrant population can significantly increase the risk of loan default and impact the interest rate. The 
findings are very much similar with Minar, \& Halim, (26) where theoretical assessments have been made to confirm the findings.

Raharjo et al. [27] analyze the determinants of interest margin of commercial banks of Indonesia for 2008-2012. They highlighted both internal and external factors affecting the interest margin of commercial banks. Depending on the level of significance, all the internal factors such as the growth of the bank's assets, profitability, efficiency, capital adequacy, liquidity, and risk affect the interest margin of commercial banks. At the same time, inflation is the only external variable impacting the interest margin. However, the research time frame is not that long period.

Shahzad et al. [28] investigate the determinants of interest rate spread of the Pakistani banking sector. It considers banklevel, market level, and macroeconomic variables to determine its impact on interest rate spread. Operating costs, non-interest revenue, concentration ratio, market size, corruption, domestic borrowing, fiscal deficit, exchange rate, inflation, money circulation, and government expenditure are the influential factors of the interest rate spread of banks in Pakistan.

Younus \& Mujeri [5] elucidate the internal and external factors affecting the interest rate spread of 48 commercial banks of Bangladesh from 2004 to 2008. Results reveal that operating costs and classified loans affect the interest rate spread of state-owned and specialized commercial banks. In contrast, contributory factors for the private commercial banks are inflation, operating costs, market share of deposits, statutory reserve requirements, and taxes. And also, noninterest income, inflation, market share, and taxes are significant for foreign commercial banks. (FCBs). In developing countries, foreign-owned banks enjoy higher interest rate spreads than domestically owned banks (Huizinga, 1998).

Crowley [29] explored the behavior of interest rate spread of banks of countries in English-speaking Africa over 19772003. A good number of bank-level data, industry-level data, and macroeconomic data have been analyzed here to find out the strong impact of these data on the interest rate spread of banks. The results demonstrate that lower inflation, a more significant number of banks, and greater public ownership, lead to enhanced interest rate spread. In contrast, a higher deposit rate leads to having a lower interest rate spread of banks. Besides, variables like non-performing loans and the size of the banking sector were not significant in affecting the interest rate spread of banks.

Empirical work by Wilkens et al. on German universal banks for 2000-2009 reveals that higher market power enhances the interest income margin and greater volatility of interest rates, leading to increased interest rate margins. And also, the risk aversion of a bank affects the interest income and the negative correlation between credit risk and interest rate. Pramanik [30] and Pramanik, \& Polansky [31] developed an optimization technique to indemnify the macroeconomic variables that impact the interest rate spread.

\section{ReSEARCH Methodology}

\section{A. Research Design}

A descriptive quantitative research design has been employed as the study has included quantitative data for measuring independent and dependent variables undertaken.

\section{B. Data \& Variables}

This study's data consists of 15 conventional commercial banks of Bangladesh listed at the Dhaka Stock Exchange (DSE). The annual report of these banks is used to collect the related data from 2011-2019.

\section{Dependent Variable \\ 1) Interest rate spread}

There are two ways of measuring interest rate spread of banks. In the first way, Interest rate spread has been expressed as the difference between interest income received by a bank and interest paid by it over the year taken as a ratio of total assets.

The second way of calculating IRS shows the difference between two ratios: (i) ratio of interest received and all interest-bearing assets; and (ii) ratio of interest paid and all interest earning liabilities.

Thus,

\section{IRS1 $=($ interest received interest paid $) /$ total assets}

IRS2= (interest received /all interest-bearing assets) (interest paid/all interest earning liabilities)

In addition, Interest rate spread (IRS) can also be calculated by this way as follows:

IRS=Interest gained from loans/total loans - interest paid to deposits/total deposits.

Brock \& Suarez [32] provided a narrow concept and a broad concept to measure the interest rate spread. The narrow concept includes loans in the asset side as well as deposits in the liability side. On the other hand, the broad concept of measuring IRS focuses on all interest earning assets and liabilities as well associate fees and commissions.

However, the most common way of measuring IRS derived from the literature is that IRS is the difference between interest income and interest expenses as a percentage of total earning assets. So, IRS of present study has been calculated by the way given below:

\section{IRS = (interest received /all interest-bearing assets $)-$ (interest paid/all interest earning liabilities)}

\section{Independent Variables}

\section{1) Credit risk}

The credit risk is measured by the ratio of non-performing loan to total loans keeping in consistency with the previous empirical research works. Banks with higher credit risk are likely to expect higher interest as compensation from the borrower which led to increase the spread. So, there exists a positive relationship between credit risk and interest rate spread. 


\section{2) Bank's size}

Bank size is determined by the log value of the total assets of a bank. Generally large size banks have the possible cost advantages because of economics of scale. In this sense, SIZE variable may have positive effect on the interest spread.

\section{3) Operating cost}

Operating cost is expressed as the ratio of Operating expenses to total net operating income. Banks incur operating cost both in deposit collection and lending. Upward pattern of operating cost indicates the inefficiency of the banks. A bank facing high operating cost would like to pass this cost to the clients which would increase the interest rate spread. Hence, there exists a linear relationship between operating cost and interest rate spread.

\section{4) Liquidity risk}

Liquidity risk is indicated by the ratio of deposit to liabilities. It reflects the true liquidity position which is a good measurement. Bank with greater liquidity face less liquidity risk which implies that they do not charge premium for it. As result, the spread would remain low. On the other hand, banks facing less liquidity would face liquidity risk indicating that they would impose high liquidity premium for bearing the risk. Therefore, there exist positive relationship between liquidity risk and interest rate spread of banks. [14].

\section{5) Net interest income as a ratio of total income}

Banks that mostly depend on interest income more than non-interest income are likely to enjoy higher interest spread as they can make loans at a higher rate of interest. However, this may not happen always as sometimes higher probability of loan repayment keeps the spread lower. This is due to the lower credit risk associated with loan which charges also a lower rate of interest.

\section{6) Capital adequacy}

Capital adequacy ratio reflects the amount of risk-capital that banks have to keep for the risks they take [33]. It is expressed as the ratio of Tier 1 and Tier 2 capital to total risk weighted assets of banks. The impact of capital adequacy on the interest spread can be explained from two dimensions. In one side, highly capitalized banks are most financially stable which would reduce their funding cost leading to the increase of the spread of banks. However, banks with higher capital may invest in less risky assets which would decline the spread.

\section{7) Return on Assets}

Return on assets is expressed as a ratio of net income to total assets of banks. It implies the ability of banks to the best use of its assets by declining operation cost and minimizing risks along with ensuring maximum efficiency. It is one of the indicators to evaluate the profitability of the firms relative to other firms belonging to the same industry. Therefore, a positive relationship between ROA and interest rate spread is hypothesized. In fact, higher ROA of banks influences to have higher spread as their assets are charged at a higher rate with a view to earning high return on assets.

\section{8) Market share}

It is expressed as the ratio of bank assets to total assets in an economy. Although traditional market structure conduct performance hypothesis implies that concentration and interest margins of banks are positively related, it may be negative if other factors have an influence on it [34].

\section{9) GDP growth rate}

The level of Gross Domestic product (GDP) represents the performance of economic activity of a country. Increased economic activity of a country enhances the demand for loans raising the lending rates [35]. In another scenario, growth of economic activity gifts profitable projects which reduces the credit risk that would reduce spread.

\section{0) Inflation}

Inflation shows the annual rate of inflation. Inflation may have influence on interest margins if lending and deposit rates are adjusted for changes in inflation. However, in many studies, it was found that inflation rate affects interest rates spread of banks. [36].

\begin{tabular}{|c|c|c|}
\hline Variables & Description & Expected sign \\
\hline \multicolumn{3}{|c|}{ Endogenous Variable } \\
\hline Interest rate spread (IRS) & $\begin{array}{c}\text { IRS= (interest received } \\
\text { /all interest-bearing } \\
\text { assets) - (interest } \\
\text { paid/all interest earning } \\
\text { liabilities) }\end{array}$ & \\
\hline \multicolumn{3}{|c|}{ Exogenous Variables } \\
\hline Credit risk (NPLR) & $\begin{array}{c}\text { Nonperforming loan } \\
\text { ratio }\end{array}$ & + \\
\hline Bank size (LOGA) & $\begin{array}{l}\text { Log value of Bank's } \\
\text { assets }\end{array}$ & $+/-$ \\
\hline Operating cost (OPERAT) & $\begin{array}{l}\text { Operating expense/Total } \\
\text { net operating income }\end{array}$ & + \\
\hline Liquidity risk (LR) & Deposits/total liabilities & + \\
\hline $\begin{array}{l}\text { Net interest income as a } \\
\text { ratio of total income } \\
\text { (INTRCOM) }\end{array}$ & $\begin{array}{c}\text { Net interest } \\
\text { income/Total income }\end{array}$ & $+/-$ \\
\hline Capital adequacy (CAR) & $($ Tier $1+$ Tier 2$) /$ RWA & $+/-$ \\
\hline Return on asset ratio (ROA) & Net income/Total assets & - \\
\hline Market share (MS) & $\begin{array}{l}\text { Bank assets/Total assets } \\
\text { in the banking industry }\end{array}$ & $+/-$ \\
\hline Inflation (INF) & Annual inflation rate & + \\
\hline $\begin{array}{l}\text { Gross Domestic Product } \\
\text { (LNGDP) }\end{array}$ & $\begin{array}{l}\text { Natural logarithm of } \\
\text { gross domestic products }\end{array}$ & $+/-$ \\
\hline
\end{tabular}

\section{E. Empirical Model \& Tests}

As the dataset for this study is a panel data set, to examine the research questions of the public study, a fixed-effect or a random-effect model can be used to control for time-invariant un-observables that affect both dependent and key independent variables. In particular, the fixed and randomeffect models incorporate an individual-specific timeinvariant factor, $\alpha \mathrm{i}$. If it is certain that it is not correlated with all independent variables and is normally distributed, then the random effects model would be appropriate. However, in this case, it not certain that $\alpha \mathrm{i}$ is not correlated with an independent variable. The random-effect model is used in this study with the stronger assumption required in this case. The choice of model is also consistent with the Hausman specification test.

$$
\begin{gathered}
\text { IRS }=\alpha_{\mathrm{i}}+\gamma_{\mathrm{t}}+\delta_{1} \mathrm{NPLR}_{\mathrm{ij}}+\delta_{2} \mathrm{LOGA}_{\mathrm{ij}}+\delta_{3} \mathrm{OPERA}_{\mathrm{ij}}+\delta_{4} \mathrm{LR}_{\mathrm{ij}} \\
+\delta_{5} \mathrm{INTRCOM}_{\mathrm{ij}}+\delta_{6} \mathrm{CAR}_{\mathrm{ij}}+\delta_{7} \mathrm{ROA}_{\mathrm{ij}}+\delta_{8} \mathrm{MS}_{\mathrm{ij}}+\delta_{9} \mathrm{INF}_{\mathrm{ij}}+ \\
\delta_{10} \mathrm{LNGDP}_{\mathrm{ij}}+\epsilon_{\mathrm{ij}}
\end{gathered}
$$


where,

IRS = The calculated interest rate spread for the ith bank in jth time;

$\alpha \mathrm{i}=$ Bank specific time-invariant factor;

$\gamma \mathrm{t}=$ Year-specific fixed effects;

NPLR = The credit risk;

LOGA $=$ Logarithm of the asset size of the banks;

OPERAT $=$ The operating expenses over total operating income;

LR = The liquidity risk;

INTRCOM = The net interest income over total income;

$\mathrm{CAR}=$ The capital adequacy ratio;

ROA $=$ Return on asset;

MS=Market share proxy of market power as well;

$\mathrm{INF}=$ Annual inflation rate of the year;

LNGDP $=$ Natural logarithm of gross domestic product.

\section{F. Results and Discussions}

A two-way (bank and year) random-effect model comprised of both endogenous and exogenous variables is used as a first step. In the second step, Pooled Ordinary Least Squared (POLS) has been used to check the robustness of the model. Two specifications of the relationship are used here. We explore the overall bank-specific, industry-specific, and macroeconomic variables impact on determination of interest rate spread.

\begin{tabular}{ccc}
\multicolumn{2}{c}{ TABLE II: ESTIMATED RESULTS } & \\
\hline Dependent Variable & $(1)$ & $(2)$ \\
IRS & Ordinary Least & Random-effect \\
& Square & $0.0078^{* *}$ \\
\hline Variables of interest & $0.0083^{*}$ & $(0.0208)$ \\
NPLR & $(0.0277)$ & 0.0023 \\
LOGA & -0.0062 & $(0.0123)$ \\
OPERAT & $(0.0118)$ & $0.0029^{*}$ \\
& $0.00057^{*}$ & $(0.0015)$ \\
LR & $(0.0015)$ & $0.0117 *$ \\
& $0.0139 *$ & $(0.0066)$ \\
INTRCOM & $(0.007)$ & -0.0045 \\
CAR & -0.0119 & $(0.006)$ \\
& $(0.0076)$ & 0.0372 \\
ROA & 0.0743 & $(0.0563)$ \\
& $(0.0655)$ & -0.005 \\
MS & -0.0021 & $(0.0116)$ \\
& $(0.0111)$ & -0.0188 \\
INF & -0.0351 & $(0.0908)$ \\
& $(0.0914)$ & 0.0759 \\
LNGDP & 0.0564 & $(0.0656)$ \\
& $(0.0588)$ & -0.0413 \\
& 0.1122 & $(0.1972)$ \\
\hline
\end{tabular}

* $10 \%$ Significance level.

$* * 5 \%$ Significance level.

$* * * 1 \%$ Significance level.

The estimated results by both the ordinary least square method and the random-effect method are showing some consistency. The OLS and random-effect method show that non-performing loans have a significant and positive effect on interest rate spread. The higher amount of non-performing loans increases the cost of capital for the banks and forces the interest rate for outstanding loans to go up. The interest rate gap between deposits and loans increases that affects the overall interest rate spread. The bank's operating costs have a significant and positive effect on the interest rate under both methods. The operating costs are associated with the daily operation of the banking business. Higher operating costs need to be covered through higher income and the increase in the interest rate spread increases the profit margin for the banks. A higher deposit rate reduces increases liquidity and decreases the overall interest rate of the deposits — both OLS and the random-effect model exhibit the positive and significant impact of deposit on interest rate spread. The net interest income has a negative and insignificant impact on the interest rate spread. The return on the asset has a negative yet not significant impact on the interest rate spread. The higher income induces the bank to pay higher interest on deposits, reducing the interest rate gap between deposits and loans. Both OLS and random effects model finds that the higher the capital adequacy ratio, the higher the interest rate spread. As significant capital is held in liquid assets to earn a return less than the banks' capital costs, it substantially affects the interest rate spread.

The impact of bank assets on interest rate spread can be positive and negative depending on the size, managerial capacity, and other factors. The OLS method predicts that the asset size negatively impacts the interest rate spread, whereas the random effect predicts that the larger the asset size, the larger the interest rate spread. The mixed results between the two methods are fully consistent with the expected outcome. The market share is an industry-specific variable and affects the bank-specific variables significantly. The larger the bank's market share, the higher possibility that it earns more using its assets. The OLS model and random effects method finds that the market share has a negative and insignificant impact on the interest rate spread. Higher market share increases the efficiency of the banks and delivers the opportunity to enhance its quality loans.

Inflation has a substantial impact on the earnings of the banking industry. It reduces the purchasing power and the value of the currency. Inflation also increases the costs of capital and overall costs of business. The OLS and randomeffect model show that inflation has a positive effect on the interest rate spread. The higher GDP growth is good for business as it allows the banking industry to expand its assets, but this may not be true in all cases. The economic growth through less debt financing may have a negative externality on the banking business. The estimation results show that in the ordinary least square method, GDP growth positively impacts interest rate spread. In contrast, in the random-effect method, the relation is negative. The results satisfy the theoretical assumptions about the relationship.

\section{CONCLUSION}

This study highlights the factors i.e., bank-specific, industry-specific, and macroeconomic, contributing to the interest rate spread of Bangladesh's listed conventional commercial banks. It concludes that credit risk, operating costs, and liquidity risk are statistically significant and positively impact interest rate spread. At the same time, none of the bank-specific and macroeconomic factors are found to be substantial. The study suggests that banks should assess the borrower's credit risk prudently so that it would lead to determine the interest rate on loans correctly, keeping in pace with the deposit rate operating cost and liquidity risk of the bank. This study has constraints in terms of having a small sample size, using only backward-looking data, and 
excluding the impact of the recent macroeconomic shock such as COVID-19 on the interest rate spread of banks. So, further study can be undertaken to show the effects of COVID-19 on the interest rate. And also impact of financial inclusion and digital finance can also be considered in the future study.

\section{REFERENCES}

[1] Sufian F, Habibullah MS, Determinants of bank profitability in a developing economy: Empirical evidence from Bangladesh. Journal of business economics and management. 1;10(3):207-217, 2009.

[2] Huizinga H. Determinants of Commercial Bank Interest Margins and Profitability: Some International Evidence. World Bank Publications; 1998.

[3] Al Shubiri FN, Jamil SA. Assessing the determinants of interest rate spread of commercial banks in Oman: an empirical investigation. European Research Studies. 2017 Apr 1;20(2):90.

[4] Ghasemi A, Rostami M. Determinants of interest rate spread in banking industry. International Journal of Applied Research . 2015;1(9):338-46.

[5] Kujeri MK, Younus S, Hossain M, Ahmed M, Begum S, Sen B, Srinivasan TN, Quibria MG. The Bangladesh Development Studies.

[6] Were M, Wambua J. What factors drive interest rate spread of commercial banks? Empirical evidence from Kenya. Review of development Finance. 2014 Dec 1;4(2):73-82.

[7] Fofack AD. The determinants of interest rate spread: Empirical evidence from the Central African economic and monetary community. Journal of Economics and International Finance. 2016 Jul 31;8(6):6678.

[8] Wijaya C, Lucianna Y, Indriati F. Determinants of interest rate spreads of conventional banks listed on the Indonesia Stock Exchange. Banks and Bank Systems. 2020 Dec 1;15(4):69-79.

[9] Chirwa EW. Market structure, liberalization and performance in the Malawian banking industry. AERC; 2001 Jul 28.

[10] Leykun F. Factors affecting the net interest margin of commercial bank of Ethiopia. International Journal of Scientific and Research Publications. 2016 Jun;6(6):150-61.

[11] McShane RW, Sharpe IG. A time series/cross section analysis of the determinants of Australian trading bank loan/deposit interest margins: 1962-1981. Journal of Banking \& Finance. 1985 Mar 1;9(1):115-36.

[12] Allen L. The determinants of bank interest margins: A note. Journal of Financial and Quantitative analysis. 1988 Jun;23(2):231-5.

[13] Musah A, Anokye FK, Gakpetor ED. The impact of interest rate spread on bank profitability in Ghana. European Journal of Business, Economics and Accountancy. 2018;6(1):27-39.

[14] Ahamed F. Determinants of Liquidity Risk in the Commercial Banks in Bangladesh. European Journal of Business and Management Research. 2021 Feb 19;6(1):164-9.

[15] Rusuhuzwa TK, Karangwa M, Nyalihama C. Determinants of interest rate spread in Rwanda: Empirical evidence. Issues in Business Management and Economics. 2016;4(3):33-40.

[16] Hossain MS, Ahamed F. Determinants of bank profitability: A study on the banking sector of Bangladesh. Journal of Finance and Banking. 2015;13(1):43-57.

[17] Hossain MS, Ahamed F. Comprehensive Analysis On Determinants Of Bank Profitability In Bangladesh. arXiv preprint arXiv:2105.14198. 2021 May 29.

[18] Ahmed F. Corporate Boards, Audit Committees and Voluntary Disclosure: A Case Analysis on Bangladeshi Listed Companies. European Journal of Business and Management Research. $2021 \mathrm{Apr}$ 9;6(2):153-5.

[19] Khan MF. Impact of Exchange Rate on Economic Growth of Bangladesh. European Journal of Business and Management Research. 2021 Jun 10;6(3):173-5.

[20] Adeniran JO, Yusuf SA, Adeyemi OA. The impact of exchange rate fluctuation on the Nigerian economic growth: An empirical investigation. International journal of Academic Research in Business and Social sciences. 2014 Aug 1;4(8):224.

[21] Mohammad MA, Mohammad RI. Revisiting the Feldstein-Horioka Hypothesis of savings, investment and capital mobility: evidence from 27 EU countries.

[22] Alam MM, Khondker RK, Molla MS. Current Account Dynamics, Adjustment and Capital Mobility in Bangladesh. Global Disclosure of Economics and Business. 2013 Dec 31;2(2):117-26.

[23] Njeri BK, Ombui K, Kagiri A. Determinants of interest rate spread of commercial banks in Kenya. International journal of science and research. 2013;6(5):2319-7064.
[24] Minar SJ. Tatmadaw's Crackdown on The Rohingyas: A SWOT Analysis. Journal of Social Studies. 2019;5(1):1-5.

[25] Minar SJ. Grand Strategy and Foreign Policy: How Grand Strategy Can Aid Bangladesh's Foreign Policy Rethinking?. Journal of Social Studies. 2018;4(1):20-7.

[26] Abdul H. The Rohingyas of Rakhine State: Social Evolution and History in the Light of Ethnic Nationalism. Social Evolution \& History. 2020;19(2):115-44.

[27] Raharjo PG, Hakim DB, Manurung AH, Maulana TN. The determinant of commercial banks' interest margin in Indonesia: An analysis of fixed effect panel regression. International Journal of Economics and Financial Issues. 2014 Apr 1;4(2):295.

[28] Shahzad A, Lodhi KM, Athar MR. Determinants of interest rate spread: An empirical explanation. Actual Problems of Economics. 2012 Jan 1(130):46-52.

[29] Crowley J. Interest rate spreads in English-speaking African countries. IMF Working Papers. 2007 Apr 1;2007(101).

[30] Pramanik P. Optimization of market stochastic dynamics. InSN Operations Research Forum 2020 Dec (Vol. 1, No. 4, pp. 1-17). Springer International Publishing.

[31] Pramanik P, Polansky AM. Optimization of a Dynamic Profit Function using Euclidean Path Integral. arXiv preprint arXiv:2002.09394. 2020 Feb 21.

[32] Brock PL, Suarez LR. Understanding the behavior of bank spreads in Latin America. Journal of development Economics. 2000 Oct 1;63(1):113-34.

[33] Ozili PK. Banking stability determinants in Africa. International Journal of Managerial Finance. 2018 Aug 6.

[34] Ahokpossi MC. Determinants of bank interest margins in Sub-Saharan Africa. International Monetary Fund; 2013 Jan 31.

[35] Mahmoudi M. Identifying the Main Factors of Iran's Economic Growth using Growth Accounting Framework. arXiv preprint arXiv:2109.02787. 2021 Sep 7.

[36] Ho TS, Saunders A. The determinants of bank interest margins: theory and empirical evidence. Journal of Financial and Quantitative analysis. 1981 Nov;16(4):581-600.

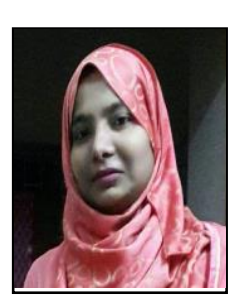

Washeka Anjom is working as a Senior Lecturer at the Department of Business Administration of Port City International University, Chittagong, Bangladesh. She completed her Bachelor of Business Administration (B.B.A) and Masters of Business Administration (M.B.A) from Department of Finance, University of Dhaka. She is involved in doing research regarding the financial system, banking industry and macroeconomic issues. 